\title{
Entrepreneurship, Transaction Costs, and Resource Attributes
}

Foss, Kirsten; Foss, Nicolai Juul

Document Version

Final published version

Publication date:

2006

License

CC BY-NC-ND

Citation for published version (APA):

Foss, K., \& Foss, N. J. (2006). Entrepreneurship, Transaction Costs, and Resource Attributes. Center for Strategic Management and Globalization. SMG Working Paper No. WP 7/2006

Link to publication in CBS Research Portal

\section{General rights}

Copyright and moral rights for the publications made accessible in the public portal are retained by the authors and/or other copyright owners and it is a condition of accessing publications that users recognise and abide by the legal requirements associated with these rights.

\section{Take down policy}

If you believe that this document breaches copyright please contact us (research.lib@cbs.dk) providing details, and we will remove access to the work immediately and investigate your claim. 


\title{
Entrepreneurship, Transaction Costs, and Resource Attributes
}

\author{
Kirsten Foss \\ Nicolai J. Foss \\ SMG WP 7/2006
}

April 2006 
SMG Working Paper No. 7/2006

April 2006

ISBN: 87-91815-23-1

Center for Strategic Management and Globalization Copenhagen Business School

Porcelænshaven 24

2000 Frederiksberg

Denmark

www.cbs.dk/smg 


\title{
ENTREPRENEURSHIP, TRANSACTION COSTS, AND RESOURCE ATTRIBUTES
}

\author{
Kirsten Foss and Nicolai Foss \\ Center for Strategic Management and Globalization \\ Copenhagen Business School \\ Porcelainshaven 24B, 2.fl; 2000 Frederiksberg; Denmark \\ kf.smg@cbs.dk; njf.smg@cbs.dk
}

Forthcoming, International Journal of Strategic Change Management

6 April, 2006

\begin{abstract}
This paper responds to Kim and Mahoney's “How Property Rights Economics Furthers the Resource-Based View: Resources, Transaction Costs and Entrepreneurial Discovery" (a comment on Foss and Foss, 2005). While we agree with many of their arguments, we argue that they fail to recognize how exactly transaction costs and property rights shape the process of entrepreneurial discovery. We provide a sketch of the mechanisms that link entrepreneurship, property rights, and transaction costs in a resource-based setting, contributing further to the attempt to take the RBV in a more dynamic direction.
\end{abstract}

\section{KEYWORDS}

Entrepreneurship, transaction costs, property rights, the resource-based view.

JEL CODE: B5, M2. 


\section{INTRODUCTION}

We are grateful to Kim and Mahoney (2006) for their friendly critique of our 2005 paper, "Resources and Transaction Costs: How Property Rights Economics Furthers the Resourcebased View." We agree with most of their arguments and in particular with their attempt to link ideas on entrepreneurship to ideas on property rights and transaction costs. However, their linking of these ideas does not go sufficiently far.

It has been argued that “... in transaction cost economics, the functioning market is as much a black box as is the firm in neoclassical microeconomic theory” (Holmström and Roberts 1998: 77). In particular, entrepreneurship — a crucial part of "the functioning market" - is

missing from current thinking on property rights and transaction costs, and Kim and Mahoney go some way in linking these. However, we argue that Kim and Mahoney do not go sufficiently far in linking ideas on transaction costs, property rights, and entrepreneurship. Kim and Mahoney rightly point to “... how property theory ... in conjunction with resourcebased theory [can] allow us to understand economic rent generation as a dynamic process" (p.2). However, we believe that it is possible to be more precise with respect to how exactly property rights and transaction costs shape the process of entrepreneurial discovery. In this paper, we provide a sketch of the mechanisms that link entrepreneurship, strategic rents, and transaction costs in a resource-based setting, thus contributing further to the attempt to take the RBV in a more dynamic direction.

\section{ENTREPRENEURSHIP AND TRANSACTION COSTS}

\section{Entrepreneurship as Judgment}

Like Kim and Mahoney (2006), we consider Austrian economics to be a natural complement to notions of property rights and transaction costs (see also Littlechild, 1986; Foss and Foss, 2000; Kim and Mahoney, 2002; Foss, Foss, Klein and Klein, 2006). Modern Austrian economists (such as Kirzner 1973; O’Driscoll and Rizzo 1985; Littlechild 1986) view economic activities as ongoing processes of discovery. In this conception, agents' plans are based on incomplete, imperfect and subjectively held knowledge about the plans of other agents. This results in behavior that is off the equilibrium path and in the emergence of disequilibrium prices. Also, equilibria may be upset by Schumpeterian entrepreneurs (Schumpeter, 1934). However, alert arbitraging entrepreneurs “... grasp the opportunities for 
pure entrepreneurial profit created by temporary absence of full adjustment” (Kirzner 1997: 69), and restore a tendency towards equilibrium.

Foss, Foss, Klein and Klein (2006) develop the concept of entrepreneurship as judgment drawing on Knight (1921), Mises (1949) and Casson (1982). This view traces its origins to the first systematic treatment of entrepreneurship in economics, Cantillon's Essai sur la nature de commerce en géneral (1755). It conceives entrepreneurship as judgmental decisionmaking under conditions of uncertainty. Judgment refers primarily to business decision-making when the range of possible future outcomes, let alone the likelihood of individual outcomes, is generally unknown (what Knight terms uncertainty, rather than mere probabilistic risk). More generally, judgment is required "when no obviously correct model or decision rule is available or when relevant data is unreliable or incomplete” (Casson, 1982: 17). Judgment must be exercised even in mundane circumstances, as Knight (1921) emphasized, for ongoing operations as well as new ventures. ${ }^{1}$

Knight (1921) introduced judgment in order to link profit and the firm to uncertainty. Judgment primarily refers to the process of businessmen forming estimates of future events in situations in which the relevant probability distributions are themselves unknown. Entrepreneurship represents judgment that cannot be assessed in terms of its marginal product and which cannot, accordingly, be paid a wage (Knight, 1921: 311). In other words, there is no market for the judgment that entrepreneurs rely on, and therefore exercising judgment requires the person with judgment to start a firm. Of course, judgmental decision makers can hire consultants, forecasters, technical experts, and so on. However, in doing so they are exercising their own entrepreneurial judgment. Judgment thus implies asset ownership, for judgmental decisionmaking is ultimately decision-making about the employment of resources (or, as we shall later argue, of resource attributes).

The notion of entrepreneurship as judgment implies an obvious link with the theory of the firm, particularly those theories (transaction cost economics and the property-rights approach)

\footnotetext{
${ }^{1}$ Somewhat in contrast, in Kirzner's treatment, entrepreneurship is characterized as “... a responding agency. I view the entrepreneur not as a source of innovative ideas ex nihilo, but as being alert to the opportunities that exist already and are waiting to be noticed" (Kirzner, 1973: 74).
} 
that put asset ownership at the forefront of firm organization (Williamson, 1996; Hart, 1995) (cf. also Langlois and Cosgel, 1993). ${ }^{2}$ However, there is also close link to Penrose's (1959) theory of the firm, and particularly to her notion of the management team that based on heterogenous and path-dependent experience formulates an image of the firm's "productive opportunity set” (Kor and Mahoney, 2000).

\section{Entrepreneurship and Transaction Costs}

Foss and Foss (2005) asked what would happen to resource value and resource-based strategies in a world of zero transaction costs, and then discussed the implications of introducing transaction costs. Consider the same kind of thought experiment, this performed with respect to entrepreneurship.

What does it mean to say that transaction costs are zero? In one interpretation, “... zero transaction costs includes the assumption that information about others' characteristics is common knowledge” (Makowski and Ostroy, 2001: 531). In Coase's (1988) own interpretation (as well as in Barzel, 1997), zero transaction costs include this, as well as considerable (perhaps perfect) foresight. Thus, zero transaction costs literally means that present and future resource uses are known to decision-makers. In such a world, there is no scope for entrepreneurship.

However, such a world implies unrealistic cognitive powers on the part of decision-makers. And

... given the constraints affecting the availability of information and human cognitive capacity, each decision-maker has only partial understanding of the options extant in society, and it is no longer possible to assume that each person knows everything about current technological alternatives, the nature and availability of all productive resources, the existence and true properties of every commodity in the system” (Furubotn, 2002: 75).

A world of positive transaction cost is therefore one in which judgment has to be exercised with respect to future resource uses. This cognitive capacity is not necessary in a world of

\footnotetext{
${ }^{2}$ The firm is defined as the entrepreneur plus the alienable assets he owns and therefore ultimately controls. As Foss, Foss, Klein and Klein (2006) The theory of the firm then becomes a theory of how the entrepreneur arranges his heterogeneous capital assets - what combinations of assets will he seek to acquire, what (proximate) decisions will he delegate to subordinates, how will he provide incentives and use monitoring to see that his assets are used consistently with his judgments, and so on.
} 
zero transaction costs, as all resource uses will effectively be mediated by the price system. In this sense, the existence of transaction costs makes possible the exercise of entrepreneurship conceived of as judgment. However, there are further links between transaction costs and entrepreneurship on this fundamental level.

Assume that the economy is initially in a state of equilibrium, but with positive transaction costs. All entrepreneurial activities have ceased. Some shock then disturbs the economy, for example, some essential input that is used in the production of several products becomes scarce (as in Hayek, 1945). In a zero transaction cost world, “... when equilibrium is disturbed a new equilibrium is instantaneously attained because, given zero transaction costs, the cost of adjustment is zero" (Barzel, 1997: 11). In particular, there is no need for entrepreneurs to equilibrate markets. However, the economy under examination is one where transaction costs are zero. And “[w]hen equilibrium is disturbed in a positive transaction cost world, price adjustment is not expected to be instantaneous” (Barzel, 1997: 12). "Menu costs," contractual costs of all sorts, costs of searching for alternative exchange partners, etc. imply that price adjustment is sluggish. In this world, (Kirznerian) entrepreneurs step in to equilibrate markets based on their alert perception of profit opportunities. In sum, transaction costs and entrepreneurship can be neatly linked. The next step is linking entrepreneurship to property rights.

\section{DISCOVERING RESOURCE ATTRIBUTES}

In order to see how entrepreneurship connects to issues of property rights, it is convenient to take the work of Barzel (1997) as a starting point. He consistently defines notions of property rights in terms of expectations in a way that is consistent with the Austrian emphasis on subjectivism (e.g., O’Driscoll and Rizzo 1985). Thus, Barzel (1994: 394) defines a property right as “... an individual's net valuation, in expected terms, of the ability to directly consume the services of the asset, or to consume it indirectly through exchange.” Property rights can be hold to attributes of an asset Attributes are characteristics and possible uses of assets.

In Foss and Foss (2005) we make use of the idea in property rights theory that resources are bundles of attributes. ${ }^{3}$ Although Barzel stresses property rights to known attributes of

\footnotetext{
${ }^{3}$ Kim and Mahoney (2006: 10) instead define resources as bundles of property rights. While resource value is determined by the property rights that are held to the attributes of a resource, we think that resources should be defined in terms of attributes.
} 
resources as the relevant units of analysis, we think it is important to stress that most assets have multiple non-specified and not yet discovered attributes. For example, a parcel of land can be used for building houses or a factory, for recreational purposes and so on. The owner of the parcel buys the rights to exploit a bundle of attributes. Some of the attributes will be known to buyer and seller at the time of trade while some will be unknown. Thus, the buyer may acquire the parcel to build a factory and as the builders prepare the foundation of the building, they may discover an oil well (an unknown attribute). The owner earns a pure windfall profit from this discovery. The value to the resource owner of the attribute depends on whether he holds secure property rights to the relevant attribute.

Thus, property rights matter even in the case of pure luck. However, the discovery of many resource attributes is not a matter of pure luck; it is part of an entrepreneurial discovery process (as argued above) and this process is strongly influenced by property rights because they influence which of the attributes that are known to entrepreneurs they will explore and therefore their judgment and their entrepreneurial actions. However, the discovery of resource attributes often is path dependent and when entrepreneurs decide not to explore certain attributes, they implicitly cut themselves off from the discovery of a number of other attributes. ${ }^{4}$ In other words, property rights steer the entrepreneurial discovery process. For example, if the entrepreneur cannot hold (sufficiently) secure property rights to certain resource attributes, he will not explore these and certain resource attributes may therefore never be discovered and explored.

The general idea is that property rights and the transaction costs involved in defining and securing property rights strongly influence an entrepreneur's expectations regarding the value of the attribute that he can appropriate. If the entrepreneur is able to discover ways of reducing the relevant transaction costs, such discovery influence his expectations regarding the value he can appropriate from resources. For this reason we expect entrepreneurs to be engaged in searching for ways of reducing transaction costs. This is the kind of entrepreneurship that was implicitly addressed in Foss and Foss (2005). For example, new ways of defining (e.g., better ways of measuring attributes), protecting (e.g., ways of protecting credit card information in virtual exchanges), and exchanging (e.g., internet trade) property rights result from entrepreneurial action.

\footnotetext{
${ }^{4}$ They may still know that these attributes exist although they do not explore their precise characteristics.
} 
However, we recognize that entrepreneurship involves more than reducing transaction cost impediments to the definition, protection and exchange of property rights. Entrepreneurship also involves discovering new resource attributes themselves, as stated above. However, our main point here is that these two aspects of entrepreneurship are highly interdependent! Thus, reduction of the costs of defining, protecting and exchanging property rights brought about by entrepreneurial action can be expected to impact the entrepreneurs' judgment with respect to the value of hitherto unexplored attributes.

As an example, consider the firm. The firm arguably lowers the costs of combining and recombining knowledge resources relative to market exchange (as recognized by Kim and Mahoney, 2006). One reason is that property rights to such resources are better protected inside firms than in markets. Arguably, firms may also have advantages in measuring knowledge resources (Alchian and Demsetz, 1972). “Combinative capabilities” (Kogut and Zander, 1992) have a significant transaction cost dimension. These transaction costs advantages allow for more entrepreneurial exploration of the attributes of knowledge assets than markets do. Thus, the modern firm allowed for an exploration of attributes that would not have taken place in its absence. In fact, much the same can be argued for the institutions that support market exchange (cf. Casson, 1982; Loasby 1994). Contracts, reputation mechanisms, contract law, product warranties, standards, etc. reduce the costs of combining and recombining (typically, non-knowledge) resources. Such entrepreneurial institutionmaking may be seen as representing discontinuities in terms of reducing the costs of exploring numerous resource combinations (of course, there are also more incremental processes taking place in the interstices of established institutions; Langlois, 1992).

\section{CONCLUSION: IMPLICATIONS FOR THE RESOURCE-BASED VIEW}

Kim and Mahoney (2006: 14) extend Foss and Foss (2005) to include “... not only economizing on transaction costs, but also the dynamic search for increasing entrepreneurial rent.” Our contributions in this comment on Kim and Mahoney is to point out that economizing on transaction cost and entrepreneurship are intertwined, and to suggest some ways in which transaction costs shape the process of entrepreneurial discovery. Several implications for the resource-based view follow from our discussion.

Implications for strategic factor markets. In an important contribution to the RBV, Barney (1986) argued that luck or asymmetrical information on the demand side of input markets 
("strategic factor markets") are necessary for competitive advantage. If the supply and demand side of the market hold identical information sets, they will arrive at identical estimates of the contribution of a resource to value creation. With reasonably competitive input markets, the price of a resource will equal its discounted net present value. However, this argument abstracts from entrepreneurial judgment and how it is linked to transaction costs. Judgment goes beyond the asymmetrical information paradigm assumed in Barney (1986). Thus, other agents are fundamentally ignorant about the contents of the entrepreneur's vision (Knight, 1921; Langlois and Cosgel, 1993); they don't know that there are things they don't know (whereas in the asymmetrical information paradigm, agents know what they lack information about, cf. Littlechild, 1986; Kirzner, 1997). Moreover, we have argued that transaction costs influence the exercise of judgment; for example, entrepreneurs may refrain from forming judgments over the use of resource attributes that are costly to protect. This means that the expectations entrepreneurs form over the values of resource attributes are influenced by transaction cost. Equilibria on strategic factor markets are therefore constrained by transaction costs. A further implication is that if the costs of protecting a certain resource attribute are lowered, this attribute may become more attractive for the entrepreneur. It may become part of entrepreneurial judgment. For example, the invention of barbed wire introduced a number of new uses of land, including new ways of raising cattle. Entrepreneurs that understand the implications of changing transaction costs for resource uses may be in a position to beat the supply side on strategic factor markets in the sense of acquiring resources at a price below the discounted net present value.

Resource value. The role of the entrepreneur is to discover valuable attributes. He will tend to look for attributes that give rise to rents. We argue that firms' ability to earn rents is intimately linked with to the creation and enforcement of property rights over attributes (Foss and Foss, 2005). In turn creation and enforcement of property rights depend on the transaction costs involved in these activities. For these reasons the value of resources is partly an outcome of the process of discovering attributes of the resource and partly of economizing with transaction costs incurred in exploiting these attributes. Foss and Foss (2005) concentrated on how economizing with transaction costs influences resource value. Kim and Mahoney (2006) argued that the understanding of the discovery of new resource uses should be integrated with the RBV. However, as we have argued, reducing transaction costs and discovering new 
resource attributes are closely related phenomena, and both are important for understanding resource value.

Sustainability and the dynamics of rents. The sustainability of competitive advantage and/or rents is usually treated as an equilibrium phenomenon (Lippman and Rumelt, 1982; Barney, 1991). This is partly because differential rents are ill-defined outside equilibrium (Lippman and Rumelt, 2003), and partly because the interpretation of sustainability as a situation in which all attempts at imitating (Lippman and Rumelt, 1982) or substituting (Barney, 1991) a successful firm's resource portfolio have ceased is in itself an equilibrium conception. Technological changes are commonly seen as the factor that changes the distribution of competitive advantages in an industry. However, changes in transaction costs may play this role. First, a reduction of transaction costs is also a reduction of the costs of combining and recombining resources, which in turn makes it more attractive for entrepreneurs to try to substitute the resource bundles of successful firms. Second, the reduction of the costs of combining and recombining resources imply that the cost of innovation are lowered. Third, changes in transaction costs imply changes in the costs of imitation (see Foss and Foss, 2005). 


\section{REFERENCES}

Alchian, Armen A. and Harold Demsetz. 1972. "Production, Information Costs, and Economic Organization,” American Economic Review 62: 772-795.

Barney, Jay B. 1986. ”Strategic Factor Markets,” Management Science 32: 1231-1241.

Barney, Jay B. 1991. "Firm Resources and Sustained Competitive Advantage”, Journal of Management 17: 99-120.

Barzel, Yoram. 1982. "Measurement Costs and the Organization of Markets," Journal of Law and Economics 25: 27-48.

Barzel, Yoram. 1994. "The Capture of Wealth by Monopolists and the Protection of Property Rights,” International Review of Law and Economics 14: 393-409.

Barzel, Yoram. 1997. Economic Analysis of Property Rights, 2nd ed., Cambridge: Cambridge University Press.

Cantillon, Richard. 1755. Essai sur la nature de commerce en géneral. Henry Higgs, ed. London: Macmillan, 1931.

Casson, Mark C. 1982. The Entrepreneur: An Economic Theory. Oxford: Martin Robertson, 2nd. ed. Edward Elgar, 1999.

Coase, Ronald H. 1960. "The Problem of Social Cost,” in idem. 1988. The Firm, the Market and the State. Chicago: University of Chicago Press.

Coase, Ronald H. 1988. The Firm, the Market, and the Law. Chicago: University of Chicago Press.

Coase, Ronald H. 1992. “The Institutional Structure of Production,” American Economic Review 82: 713-719.

Foss, Nicolai J. and Kirsten Foss. 2000. "Theoretical Isolation in Contract Economics," Journal of Economic Methodology 7: 313-339.

Foss, Kirsten and Nicolai Foss. 2005. "Resources and Transaction Costs: How Property Rights Economics Furthers the Resource-based View," Strategic Management Journal 26: 541-555.

Foss, Kirsten, Nicolai Foss, Peter G. Klein, and Sandra Klein. 2006. ”The Entrepreneurial Organization of Heterogeneous Capital," Journal of Management Studies (forthcoming).

Furubotn, Eirik G. 2002. "Entrepreneurship, Transaction Cost Economics and the Design of Contracts," in Eric Brousseau and Jean-Michel Glachant, eds. Contract Theory in Prospect and Retrospect. Cambridge: Cambridge University Press.

Hart, Oliver. 1995. Firms, Contracts and Financial Structure. Oxford: Clarendon Press.

Hayek, Friedrich A. von. 1945. "The Use of Knowledge in Society," in idem. 1948. Individualism and Economic Order. Chicago: University of Chicago Press.

Holmström, Bengt and John Roberts. 1998. “The Boundaries of the Firm Revisited,” Journal of Economic Perspectives 12: 73-94. 
Kim, Jongwook, and Joseph T. Mahoney. 2002. "Resource-Based and Property Rights Perspectives on Value Creation: The Case of Oil Field Unitization.” Managerial and Decision Economics 23(4): 225-45.

Kim, Jongwook and Joseph T. Mahoney. 2006. "How Property Rights Theory Furthers the Resource-based View: Resources, Transaction Costs and Entrepreneurial Discovery," forthcoming in International Journal of Strategic Change Management.

Kirzner, Israel M. 1973. Competition and Entrepreneurship. Chicago: University of Chicago Press.

Kirzner, Israel M. 1997. "Entrepreneurial Discovery and the Competitive Market Process: An Austrian Approach,” Journal of Economic Literature 35: 60-85.

Knight, Frank H. 1921. Risk, Uncertainty, and Profit. New York: August M. Kelley.

Kogut, Bruce and Udo Zander. 1992. "Knowledge of the Firm, Combinative Capabilities, and the Replication of Technology,” Organization Science 3: 383-397.

Kor, Yasemin and Joseph T. Mahoney. 2000. "Penrose’s Resource-Based Approach: The Process and Product of Research Creativity.” Journal of Management Studies 37(1): 109_ 39.

Langlois, Richard N. 1992. "Transaction-Cost Economics in Real Time,” Industrial and Corporate Change 1: 99-127.

Langlois, Richard N. and Metin Cosgel. 1993. "Frank Knight on Risk, Uncertainty, and the Firm: A New Interpretation,” Economic Inquiry 31: 456-65.

Lippman, Steven A. and Rumelt, Richard P. 1982. "Uncertain imitability: an analysis of inter firm deficiency under competition”. The Bell Journal of Economics 13: 418-438.

Lippman, Steven A. and Rumelt, Richard P. 2003.“The Payments Perspective”. Strategic Management Journal. 24: 903-927.

Littlechild, Stephen. 1986. “Three Types of Market Process,” in Richard N. Langlois, ed. 1986. Economics as a Process. Cambridge: Cambridge University Press.

Loasby, Brian J. 1994. “Understanding Markets,” Working Paper.

Makowski, Louis and Joseph M. Ostroy. 2001. "Perfect Competition and the Creativity of Markets," Journal of Economic Literature 39: 479-535.

Mises, Ludwig von. 1949. Human Action. London: William Hodge.

O’Driscoll, Gerald P. and Mario Rizzo. 1985. The Economics of Time and Ignorance. Oxford: Basil Blackwell.

Penrose, Edith T. 1959. The Theory of the Growth of the Firm. Oxford: Oxford University Press.

Schumpeter, Joseph A. 1934. The Theory of Economic Development: An Inquiry into Profits, Capital, Credit, Interest, and the Business Cycle. Cambridge, Mass., Harvard University Press.

Williamson, Oliver E. 1996. The Mechanisms of Governance. Oxford: Oxford University Press. 


\section{SMG - Working Papers \\ www.cbs.dk/smg \\ 2003}

2003-1: Nicolai J. Foss, Kenneth Husted, Snejina Michailova, and Torben Pedersen: Governing Knowledge Processes: Theoretical Foundations and Research Opportunities.

2003-2: Yves Doz, Nicolai J. Foss, Stefanie Lenway, Marjorie Lyles, Silvia Massini, Thomas P. Murtha and Torben Pedersen: Future Frontiers in International Management Research: Innovation, Knowledge Creation, and Change in Multinational Companies.

2003-3: Snejina Michailova and Kate Hutchings: The Impact of In-Groups and OutGroups on Knowledge Sharing in Russia and China CKG Working Paper.

2003-4: Nicolai J. Foss and Torben Pedersen : The MNC as a Knowledge Structure: The Roles of Knowledge Sources and Organizational Instruments in MNC Knowledge Management CKG Working Paper.

2003-5: Kirsten Foss, Nicolai J. Foss and Xosé H. Vázquez-Vicente: “Tying the Manager's Hands": How Firms Can Make Credible Commitments That Make Opportunistic Managerial Intervention Less Likely CKG Working Paper.

2003-6: Marjorie Lyles, Torben Pedersen and Bent Petersen: Knowledge Gaps: The Case of Knowledge about Foreign Entry.

2003-7: Kirsten Foss and Nicolai J. Foss: The Limits to Designed Orders: Authority under "Distributed Knowledge" CKG Working Paper.

2003-8: Jens Gammelgaard and Torben Pedersen: Internal versus External Knowledge Sourcing of Subsidiaries - An Organizational Trade-Off.

2003-9: Kate Hutchings and Snejina Michailova: Facilitating Knowledge Sharing in Russian and Chinese Subsidiaries: The Importance of Groups and Personal Networks Accepted for publication in Journal of Knowledge Management.

2003-10: Volker Mahnke, Torben Pedersen and Markus Verzin: The impact of knowledge management on MNC subsidiary performance: the role of absorptive capacity CKG Working Paper.

2003-11: Tomas Hellström and Kenneth Husted: Mapping Knowledge and Intellectual Capital in Academic Environments: A Focus Group Study Accepted for publication in Journal of Intellectual Capital CKG Working Paper.

2003-12: Nicolai J Foss: Cognition and Motivation in the Theory of the Firm: Interaction or "Never the Twain Shall Meet"? Accepted for publication in Journal des Economistes et des Etudes Humaines CKG Working Paper.

2003-13: Dana Minbaeva and Snejina Michailova: Knowledge transfer and expatriation practices in MNCs: The role of disseminative capacity.

2003-14: Christian Vintergaard and Kenneth Husted: Enhancing selective capacity through venture bases. 


\section{4}

2004-1: Nicolai J. Foss: Knowledge and Organization in the Theory of the Multinational Corporation: Some Foundational Issues

2004-2: Dana B. Minbaeva: HRM practices and MNC knowledge transfer

2004-3: Bo Bernhard Nielsen and Snejina Michailova: Toward a phase-model of global knowledge management systems in multinational corporations

2004-4: Kirsten Foss \& Nicolai J Foss: The Next Step in the Evolution of the RBV: Integration with Transaction Cost Economics

2004-5: Teppo Felin \& Nicolai J. Foss: Methodological Individualism and the Organizational Capabilities Approach

2004-6: Jens Gammelgaard, Kenneth Husted, Snejina Michailova: Knowledge-sharing Behavior and Post-acquisition Integration Failure

2004-7: Jens Gammelgaard: Multinational Exploration of Acquired R\&D Activities

2004-8: Christoph Dörrenbächer \& Jens Gammelgaard: Subsidiary Upgrading? Strategic Inertia in the Development of German-owned Subsidiaries in Hungary

2004-9: Kirsten Foss \& Nicolai J. Foss: Resources and Transaction Costs: How the Economics of Property Rights Furthers the Resource-based View

2004-10: Jens Gammelgaard \& Thomas Ritter: The Knowledge Retrieval Matrix: Codification and Personification as Separate Strategies

2004-11: Nicolai J. Foss \& Peter G. Klein: Entrepreneurship and the Economic Theory of the Firm: Any Gains from Trade?

2004-12: Akshey Gupta \& Snejina Michailova: Knowledge Sharing in Knowledge-Intensive Firms: Opportunities and Limitations of Knowledge Codification

2004-13: Snejina Michailova \& Kate Hutchings: Knowledge Sharing and National Culture: A Comparison Between China and Russia

\section{5}

2005-1: Keld Laursen \& Ammon Salter: My Precious - The Role of Appropriability Strategies in Shaping Innovative Performance

2005-2: Nicolai J. Foss \& Peter G. Klein: The Theory of the Firm and Its Critics: A Stocktaking and Assessment

2005-3: Lars Bo Jeppesen \& Lars Frederiksen: Why Firm-Established User Communities Work for Innovation: The Personal Attributes of Innovative Users in the Case of Computer-Controlled Music

2005-4: Dana B. Minbaeva: Negative Impact of Hrm Complementarity on Knowledge Transfer in Mncs

2005-5: Kirsten Foss, Nicolai J. Foss, Peter G. Klein \& Sandra K. Klein: Austrian Capital Theory and the Link Between Entrepreneurship and the Theory of the Firm 
2005-1: Nicolai J. Foss: The Knowledge Governance Approach

2005-2: Torben J. Andersen: Capital Structure, Environmental Dynamism, Innovation Strategy, and Strategic Risk Management

2005-3: Torben J. Andersen: A Strategic Risk Management Framework for Multinational Enterprise

2005-4: Peter Holdt Christensen: Facilitating Knowledge Sharing: A Conceptual Framework

2005-5 Kirsten Foss \& Nicolai J. Foss: Hands Off! How Organizational Design Can Make Delegation Credible

2005-6 Marjorie A. Lyles, Torben Pedersen \& Bent Petersen: Closing the Knowledge Gap in Foreign Markets - A Learning Perspective

2005-7 Christian Geisler Asmussen, Torben Pedersen \& Bent Petersen: How do we capture "Global Specialization" when measuring firms' degree of internationalization?

2005-8 Kirsten Foss \& Nicolai J. Foss: Simon on Problem-Solving: Implications for New Organizational Forms

2005-9 Birgitte Grøgaard, Carmine Gioia \& Gabriel R.G. Benito: An Empirical Investigation of the Role of Industry Factors in the Internationalization Patterns of Firms

2005-10 Torben J. Andersen: The Performance and Risk Management Implications of Multinationality: An Industry Perspective

2005-11 Nicolai J. Foss: The Scientific Progress in Strategic Management: The case of the Resource-based view

2005-12 Koen H. Heimeriks: Alliance capability as a mediator between experience and alliance performance: An empirical investigation into the alliance capability development process

2005-13 Koen H. Heimeriks, Geert Duysters \& Wim Vanhaverbeke: Developing Alliance Capabilities: An Empirical Study

2005-14 JC Spender: Management, Rational or Creative? A Knowledge-Based Discussion

\section{6}

2006-1: Nicolai J. Foss \& Peter G. Klein: The Emergence of the Modern Theory of the Firm

2006-2: Teppo Felin \& Nicolai J. Foss: Individuals and Organizations: Thoughts on a Micro-Foundations Project for Strategic Management and Organizational Analysis

2006-3: Volker Mahnke, Torben Pedersen \& Markus Venzin: Does Knowledge Sharing Pay? An MNC Subsidiary Perspective on Knowledge Outflows

2006-4: Torben Pedersen: Determining Factors of Subsidiary Development 
2006-5 Ibuki Ishikawa: The source of competitive advantage and entrepreneurial judgment in the RBV: Insights from the Austrian school perspective

2006-6 Nicolai J. Foss \& Ibuki Ishikawa: Towards a dynamic resource-based view: Insights from Austrian capital and entrepreneurship theory

2006-7 Kirsten Foss \& Nicolai J. Foss: Entrepreneurship, Transaction Costs, and Resource Attributes 